\title{
A note on the chemical composition of rape seed hulls and their feeding value for ruminants
}

\author{
Th. Keller, W. Kracht, S. Dänicke and H. Jeroch \\ Institute of Animal Nutrition, \\ Faculty of Agriculture, Martin-Luther-University Halle-Wittenberg \\ Emil-Abderhalden-Street 25 b, D-06108 Halle/Saale, Germany
}

(Received 13 November 1995; accepted 12 April 1996)

\begin{abstract}
The digestibility of crude nutrients and fibre fractions and metabolizable energy of rape seed hulls obtained in a process of pealing before oil extraction was evaluated by difference method in combination with dehydrated lucerne on six adult wethers.

Rape seed hulls inclusion significantly lowered the digestibility of CP and ADF and significantly increased the digestibility of crude fat of the whole ration in comparison with dehydrated lucerne fed alone. The relatively high metabolizable energy content of the rape seed hulls of about $9.2 \mathrm{MJ} \mathrm{ME} / \mathrm{kg}$ DM were based mainly on its high crude fat content. It seems that the restricted utilization of rape seed hulls is possible in ruminant nutrition.

(1) :
\end{abstract}

KEY WORDS: rape seed, hulls, chemical composition, nutritive value, ruminants

\section{INTRODUCTION}

In recent years rape has been widely grown for oil production in Europe (FAO, 1994). About $12-16 \%$ of the weight of the rape seed grain are hulls (Henkel and Mosenthin, 1989). According to a new technology it is intended to peal the rape seeds in the oil mill before or after oil extraction. The aim of pealing before the oil extraction is to improve oil quality, i.e. get a lighter coulour of oil and pealing after oil extraction is applied with the aim to increase the feeding value of rapeseed meal. It was slown that digestibility of rations with rapeseed meal by swine (Bayley and Hill, 1975; Bourdon et al., 1982) and by poultry (Leslie et al., 1973; Jones and Sibbald, 1979) increased as the amount of rape seed 
hulls was decreased. In the process of dehulling the substantial proportion of hulls is removed, and as a fibre content in this fraction is very high it might be used only in ruminant nutrition. Little work has been published on the nutritional value of the hulls when fed to ruminants till now.

\section{MATERIAL AND METHODS}

\section{Rape seed hulls}

The rape seeds used for dehulling was a black seed of 00-quality (erucic acid free, low glucosinolate variety). The dehulling was done before extraction process with a method developed by the Fa. SKET Magdeburg GmbH. The rape seed grains were conditioned, elastic deformation in a roller slot followed, the hulls cracked and there were separated by electro-separation. The fraction of rape seed hulls $(\mathrm{RH})$ was not further extracted.

\section{Animal studies}

The estimation of digestibility coefficients of crude nutrients and fibre fractions and calculation of energy content of rape seed hulls (RH) was done by difference method. The group A obtained dehydrated lucerne supplemented with vitamin-mineral mixture as only feed. In the ration of group B $15.6 \%$ lucerne was substituted on DM basis by rape seed hulls. Each digestibility trial was conducted with six adult wethers (according to Schiemann, 1981). The animals weighed about $80 \mathrm{~kg}$ and were housed separately in metabolism cages in an experimental hsouse. Food was given in two equal meals each day at 07.00 and $14.00 \mathrm{~h}$. The total feed ration of about $1200 \mathrm{~g}$ dry matter (DM) plus vitamin-mineral supplementation was adequate for maintenance. Water was offered ad libitum. After the adaptation to the rations ( 7 days) and a preliminary period of 7 days the excreta were collected every morning for another 7 days. An aliquote proportion $(15 \%)$ was stored at $+3^{\circ} \mathrm{C}$ without addition of a preservative for laboratory analysis. Feed refusals were collected at $07.00 \mathrm{~h}$ each day, weighed and included in the daily ration on DM basis.

\section{Analysis}

Crude protein was determined in the homogenized fresh excreta, the other crude nutrients, ash and fibre components (Goering and van Soest, 1970) were analyzed according to standard laboratory methods (VDLUFA, 1988) in excreta dried in $65^{\circ} \mathrm{C}$ for $24 \mathrm{~h}$. 
Gross energy of rape seed hulls was determined by adiabatic bomb calorimetry. The contents of metabolizable energy (ME) and net energy for lactation (NEL) were calculated with according to of the following equations: $\mathrm{ME}(\mathrm{MJ})=0.0312 \times \mathrm{g}$ digestible crude fat $+0.0136 \mathrm{x}$ g digestible crude fibre + $+0.0147 \times \mathrm{g}$ (digestible organic matter - digestible crude fat - digestible crude fibre) $+0.00234 \times \mathrm{g}$ crude protein (GfE, 1995)

and

$\operatorname{NEL}(\mathrm{MJ})=0.6 \times(1+0.004 \times[\mathrm{q}-57] \times \mathrm{ME}(\mathrm{q}=$ metabolizable energy/gross energy) (GEH, 1986).

The fatty acids were determinated as methylesters with gas chromatograph HP 5890 II GC (with FFAP capillar column of $30 \mathrm{~m}$ length, diameter $0.53 \mathrm{~mm}$, detection with flame ionisation detector and integration on HP 3396). The carrier gas used was helium. The content of glucosinolates was determined with high pressure liquid chromatography (EG, 1990).

\section{Statistical analysis}

Statistical analysis was performed by means of analysis of variance (acc. to Rasch et al., 1978) using the procedure of Statistica for Windows (Release 4.5, StatSoft Corp., 1992). Means of the energy content of rations and feedstuffs were compared using the Tukey-Test.

\section{RESULTS AND DISCUSSION}

\section{Chemical composition}

The crude nutrient and fibre contents of RH and dehydrated lucerne are shown in Table 1. Rape seed hulls contained about $15 \%$ crude protein and about $15 \%$ crude fat per $\mathrm{kg} \mathrm{DM}$. That is comparable with that reported by other workers (Table 1) and is a result of an incomplete separation from the seed embryo during dehulling process. The crude protein and fat content in RH was notably lower and crude fibre higher than in rape seeds (which contained about $24 \%$ crude protein, $45 \%$ crude fat and $7 \%$ crude fibre ). However, soyabean hulls normally have higher fibre content as the rape seed hulls. There is no explanation for the high ADF value of rape seed hulls which nearly equaled to NDF content.

The dehydrated lucerne was relatively high in fibre and low in crude protein, as it was harvested in a later growth stage. Quality of dehydrated lucerne was good according a sensoric evaluation, there were no visible traces of heat damage. 
TABLE 1 Crude nutrient and fibre content $(\mathrm{g} / \mathrm{kg} \mathrm{DM}$ ) of rape seed hulls (experimental and from literature) in comparison with soyabean hulls and dehydrated lucerne

\begin{tabular}{|c|c|c|c|c|c|c|}
\hline & $\begin{array}{c}\text { Rape seed } \\
\text { hulls }\end{array}$ & $\begin{array}{l}\text { Dehydrated } \\
\text { lucerne }\end{array}$ & $\begin{array}{l}\text { Rape seed } \\
\text { hulls' }\end{array}$ & $\begin{array}{l}\text { Rape seed } \\
\text { hulls }^{2}\end{array}$ & $\begin{array}{l}\text { Rape seed } \\
\text { hulls }^{3}\end{array}$ & $\begin{array}{l}\text { Sayabean } \\
\text { hulls }^{4}\end{array}$ \\
\hline & \multicolumn{2}{|c|}{ Experimental } & \multicolumn{4}{|c|}{ From literature } \\
\hline Organic matter & 943 & 905 & 962 & n.d. & 959 & 956 \\
\hline Crude protein & 147 & 162 & 153 & 239 & 154 & 99 \\
\hline Crude fat & 143 & 23 & 106 & 72 & 130 & 10 \\
\hline Crude fibre & 227 & 343 & 397 & 189 & n.d. & 420 \\
\hline $\mathrm{N}$-free extractives & 426 & 377 & n.d. & 436 & n.d. & 427 \\
\hline NDF & 535 & 483 & 712 & 503 & 658 & 670 \\
\hline $\mathrm{ADF}$ & 526 & 393 & 599 & 392 & 467 & 512 \\
\hline Hemicellulose & 9 & 90 & n.d. & n.d. & n.d. & 500 \\
\hline ADL & 263 & 92 & 165 & n.d. & n.d. & 157 \\
\hline Cellulose & 263 & 301 & n.d. & n.d. & n.d. & 13 \\
\hline
\end{tabular}

' - Bell and Shires (1982)

${ }^{2}$ - Chibowska et al. (1994)

${ }^{3}$ - McKinnon et al. (1995)

${ }^{4}$ - Mitaru et al. (1984)

n.d. - not determinated

The fatty acid composition of fat extracted from rape seed hulls was similar to that composition of rape seed oil, with a high proportion of unsaturated fatty acids (Table 2).

The content of glucosinolates was $4.2 \mu \mathrm{M} / \mathrm{g}$ fat-free $\mathrm{DM}$. That is in comparision to rape seed (Bille et al., 1983 - 17-22 $\mu \mathrm{M} / \mathrm{g}$ fat-free DM; Kallweit, $1989-31$ [10-134] $\mu \mathrm{M} / \mathrm{g}$ fat-free DM) relatively low. But it is known that the glucosinolates are mainly found in the seeds (Bertram et al., 1986).

TABLE 2

Fatty acid composition of oil from rape seed hulls, $\%$ of fat, as methylester

\begin{tabular}{lr}
\hline C 16:0 & 5.16 \\
\hline C 18:0 $18: 1$ & 1.76 \\
C 18:2 & 53.27 \\
C 18:3 & 18.28 \\
C 20:0 & 6.69 \\
C 20:1 & 0.57 \\
C 22:1 & 1.02 \\
\hline
\end{tabular}




\section{Apparent digestibility and metabolizable energy content}

The addition of rape seed hulls did not lowered significantly the digestibility of organic matter, but significantly lowered $(\mathrm{P} \leqslant 0.05)$ the digestibility of crude protein and ADF of the whole ration (Table 3). However, the apparent digestibility of crude fat, that is found only in a small amount in lucerne, substantially increased. The low fibre digestibility was surely resulting from the high content of lignin of about $260 \mathrm{~g} / \mathrm{kg} \mathrm{DM}$ of the rape seed hulls (Table 1). It should be taken into consideration that some insignificant effects found might be a result of a low amount of hulls in the ration. However, similar results were reported by McKinnon et al. (1995) who fed higher rations of rape seed hulls to growing lambs. The low digestibility of crude protein of rape seed hulls was also concluded by Finlayson (1974) based on in vitro experiments and are in agreement with the findings of Lessire et al. (1993) who fed rape seed hulls to adult cocks.

The relatively high energy content of the rape seed hulls of about $9.2 \mathrm{MJ}$ $\mathrm{ME} / \mathrm{kg} \mathrm{DM}$ (and 5.6 MJ NEL/kg DM, respectively, Figure 1) significantly increased the energy content of the mixed ration. The energy content of the rape seed hulls is in the range of oat hulls or cotton seed meal (unpealed cotton; DLG, 1991). The content of digestible energy noted by McKinnon et al. (1995) was about 9.3 MJ DE/kg DM. However, energy content of rape seed hulls based mainly on the high crude fat content that may change between $10-20 \%$ of DM depending on the dehulling process and also on the variety (Bell and Shires, 1982). The gross energy content of the rape seed hulls was about $22 \mathrm{MJ} / \mathrm{kg} \mathrm{DM}$. It means that this by-product may by alternatively used in a controlled burning process for heat generation.

TABLE 3

Digestibility of crude nutrients and fibre fractions of the rations and the rape seed hulls. \%

\begin{tabular}{ccc} 
Experimental & Calculated \\
\hline $\begin{array}{c}\text { Group A } \\
\text { Dehydrated lucerne }\end{array}$ & $\begin{array}{c}\text { Dehydrated lucerne } \\
\text { rape seed hulls }\end{array}$ & $\begin{array}{c}\text { Rape seed } \\
\text { hulls }\end{array}$ \\
\end{tabular}

\begin{tabular}{llll}
\hline Organic matter & $54.2 \pm 1.4$ & $53.5 \pm 0.8$ & $50.4 \pm 7.7$ \\
Crude protein & $63.9 \pm 0.8^{\mathrm{c}}$ & $56.6 \pm 1.1^{\mathrm{b}}$ & $12.8 \pm 7.7^{\mathrm{a}}$ \\
Crude fat & $33.9 \pm 1.3^{\mathrm{a}}$ & $60.0 \pm 2.3^{\mathrm{b}}$ & $82.7 \pm 4.4^{\mathrm{c}}$ \\
Crude fibre & $36.4 \pm 1.8^{\mathrm{b}}$ & $33.2 \pm 1.9^{\mathrm{b}}$ & $10.7 \pm 11.7^{\mathrm{a}}$ \\
N-free extractives & $67.3 \pm 1.8^{\mathrm{a}}$ & $68.8 \pm 0.8^{\mathrm{a}}$ & $75.8 \pm 4.5^{\mathrm{b}}$ \\
NDF & $38.6 \pm 2.8$ & $38.1 \pm 1.6$ & $35.8 \pm 9.6$ \\
ADF & $49.6 \pm 2.1^{\mathrm{c}}$ & $35.8 \pm 0.8^{\mathrm{b}}$ & $20.6 \pm 4.3^{\mathrm{a}}$ \\
\hline
\end{tabular}

${ }^{\prime}-\mathrm{a}, \mathrm{b}, \mathrm{c}$ mcans \pm standard deviation within rows with different letters differ significantly at $\mathrm{P}<0.05$ 


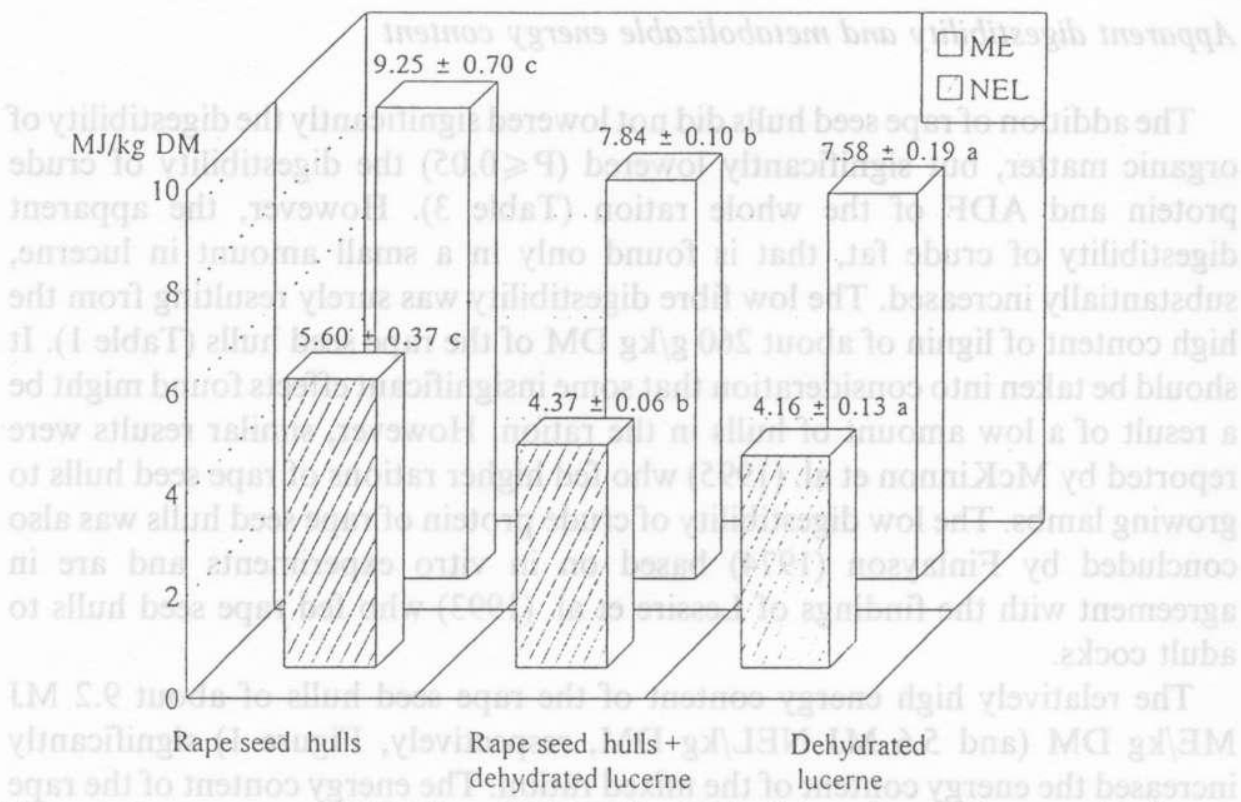

Figure 1. Energy content (MJ NEL and ME ME/kg DM) of the rations and rape seed hulls $\mathrm{a}, \mathrm{b}, \mathrm{c}-$ means \pm standard deviation within rows with different letters differ $(\mathrm{P}<0.05)$

It seems that the utilization of rape seed hulls is possible in ruminant nutrition, however it might be restricted by its high fat content.

\section{ACKNOWLEDGEMENTS}

The authors wish to thank the UFOP (Union zur Förderung von Öl- und Proteinpflanzen e.V.) for financial support of the study. The authors also gratefully acknowledge the providing of rape seed hulls of Mr. Deike (Fa. SKET Magdeburg $\mathrm{GmbH}$ ) and the determination of glucosinolates of Dr. Schumann (Gülzow). 


\section{REFERENCES}

Bayley H., Hill D.C., 1975. Nutritional evaluation of low and high fibre fractions of rapeseed meal using chickens and pigs. Can. J. Anim. Sci. 55, 223-232

Bell J.M., Shires A., 1982. Composition and digestibility by pigs of hull fractions from rapeseed meal for swine. Can. J. Anim. Sci. 55, 557-565

Bertram H.J., Brauer D., Hatje G., Henkel H., Kley G., Lange D., Lennerts L., Röbbelen G., 1986. Raps auf neuen Wagen; 00-Sorten in Züchtung, Anbau und Verwendung. Verlag Th. Mann, Gelsenkirchen-Buer

Bille N., Eggum B.O., Jacobsen I., Olsen O., Sörensen H., 1983. Antinutritional and toxic effects in rats of individual glucosinolates (+ myrosinases) added to standard died. J. Anim. Physiol. Anim. Nutr. 49, 148-163

Bourdon D., Quere P., Baudet J.J., 1982. Valeur energetique et azotec, chez le porc, d'un tourteau de colza francais a faible teneur en glucosinolates et depellicule. J. Rech. Porcine en France 14, 297-306

Chibowska M., Smulikowska S., Pastuszewska B., Alloui O., 1994. Factors effecting the metabolizable energy content of low glucosinolate rapesced oil meal and ist fractions. Proceeding of 9 th European Poultry Conference, Glasgow, Vol. I, pp. 523-524

DLG, Deutsche Landwirtschaftsgesellschaft, 1991. DLG-Futterwerttabellen-Wiederkäuer. DLG-Verlag, Frankfurt/M.

EG, 1990. Bestimmung des Ölsaatenglucosinolatgehaltes durch HPLC. Anhang VIII Verordnung (EWG Nr. 1864/90), Amtsblatt der Europäischen Gemeinschaften Nr. L 170/28, 03.07.1990

FAO, 1994. FAO-Production Yearbook 1993. Rome

Finlayson A.J., 1974. The amino acid composition of rapeseed hulls. Can. J.Anim. Sci. 54, 495-496

GEH, Gesellschaft für Ernährungsphysiologie der Haustiere, 1986. Energie- und Nährstoffbedarf landwirtschaftlicher Nutztiere, Nr. 3 Milchkühc und Aufzuchtrinder. DLG-Verlag, Frankfurt/M.

GfE, Gesellschaft für Ernährungsphysiologic, 1995. Zur Encrgiebewertung beim Wiederkäuer. Proc. Soc. Nutr. Physiol. 4, 121-123

Goering H.K., van Soest P., 1970. Forage Fibre Analysis. Handbook No. 379, U.S. Printing Office, Washington, D.C.

Henkel H., Mosenthin R., 1989. Rapssaat und Rapsprodukte in der Tierenährung. Übers. Tierernähr. 17, 139-190

Jones J.D., Sibbald I.R., 1979. The true metabolizable energy values for poultry of fractions of rapeseed (Brassica napus cv. Tower). Poultry Sci. 58, 385-391

Kallweit P., 1989. Unveröff. Untersuchungsergebnisse aus der Landwirtschaftlichen Untersuchungs-und Forschungsanstalt Kiel, cit. by Henkel and Mosenthin (1989)

Leslie A.J., Summers J.D., Jones J.D., 1973. Nutritive value of air-classified rape-seed fractions. Can. J. Anim. Sci. 53, 153.156

Lessire M., Baudet J., Hallouis J., Conan L., 1993. Metabolizable energy content and protein digestibility of rapeseed hulls in adult cockercls. Procedings of 8th International Rapeseed Congress, Saskatoon SK 5, pp.1585-1590

McKinnon J.J., Mustafa A.F., Cohen R.D.H., 1995. Nutritional evaluation and processing of canola hulls for ruminants. Can. J. Anim. Sci. 75, 231-237

Mitaru B.N., Blair R., Reichert R.D., Roe W.E., 1984. Dark and yellow rapeseed hulls, soybean hulls and a prified fiber source: their effects on dry matter, energy, protein and amino acid digestibilities in cannulated pigs. Can. J. Anim. Sci. 59, 1510-1518 
Rasch D., Herrendörfer G., Bock I., Busch K., 1978. Verfahrensbibliothek-Versuchsplanung und-auswertung. Bd. 1-3. Dte Landwverl. Berlin

Schiemann R., 1981. Methodische Richtlinien zur Durchführung von Verdauungsversuchen für die Futterwertschätzung. Arch. Anim. Nutr. 31, 1-19

VDLUFA, 1988. Methodenbuch, BD. III VDLUFA-Verlag, Darmstadt

\section{STRESZCZENIE}

Skład chemiczny okrywy nasiennej rzepaku i jej wartość odżywcza dla przeżuwaczy

Strawność surowych składników i frakcji włókna oraz energia metaboliczna okrywy nasiennej (łuski) rzepaku otrzymanej w procesie łuszczenia poprzedzającym ekstrakcję oleju zostały oznaczone metodą różnicową, w połączeniu z suszem z lucerny, na sześciu dorosłych skopach. Wlączenie łuski rzepaku istotnie obniżylo strawność białka ogólnego i ADF, oraz istotnie podwyższyło strawność tłuszczu dawki w porównaniu z dawką zawierającą wyłącznie susz z lucerny. Stosunkowo wysoka energia metaboliczna łuski rzepakowej (około 9,2 MJME/kg SM) wynikała z dużej zawartości w niej tłuszczu. Wydaje się, że możliwe jest ograniczone stosowanie łuski rzepakowej w żywieniu przeżuwaczy. 